\title{
EFEKTIVITAS PENDAYAGUNAAN BIAYA BANTUAN OPERASIONAL SEKOLAH DALAM ANGGARAN KUALITAS PENDIDIKAN SEKOLAH DASAR SWASTA DAN NEGERI
}

\author{
Suria Bakti \\ Sekolah Dasar Negeri Lung Manyo Kecamatan Manyak Payed Kabupaten Aceh Tamiang, \\ Aceh, Indonesia \\ Email: suriabakti02@gmail.com
}

\begin{abstract}
Abstrak
Dana Bos merupakan program pemerintah yang difungsikan untuk memajukan kualitas pendididkan. Permasalahan Program mutu pendidikan belum menunjukkan peningkatan yang signifikan. Disebutkan bahwa kualitas pendidikan di wilayah Negara Kesatuan Republik Indonesia masih bersain dengan Negara tetangga, Meskipun demikiani jangkauan jaringan pendidikan bagi penduduk dinyatakan mampu meningkat secara perlahan. Negara NKRI sendiri sudah menghimbau program perubahan pendidikan bagi menata kualitas sektor ini selama 17 tahun sejak 2002. Program Bantuan Operasional Sekolah bertujuan meringankan beban masyarakat di sekitar kita khusunya dalam program mengentaskan wajib belajar Sembilan tahun. Salah satu tujuan dari program BOS adalah meningkatkan prestasi belajar peserta didik di sekolah dan berpartisipasi dalam program wajib belajar semilan tahun bias di lihat dari beberapa indicator pada angka prartisipa secara kasar.selain itu juga berperan penting dalam meningkatkan efektifitas dan kualitas Pendidikan sekolah dasar(SD). Kesepakatan danatar tim menegemen dana bos sekolah secara Bersama dalam mengambil keputusan penggunaan dana bos sangat di perlukan., di samping dana yang diperoleh dari Pemerintah daerah atau sumber lain yang sah.Dengan adanya program biaya bantuan sekolah ataupun sering di sebut BOS, SD Negeri dan SD swasta yang ada di UPTD Pendidikan dan Kebudayaan V Kab. Aceh Tamiang dapat mengurangi masalah keuangan masyarakat terhadap anggaran pendidikan menuntaskan wajib belajar Sembilan tahun yang bermutu. Hal ini menunjukkan bahwa ada manfaat yang begitu besar dengan hadirnya dana BOS bagi setiap sekolah.Penelitian ini menggunakan pendekatan qualitatif, naturalistik dan tekhnik triangulasi. Pengambilan data dengan menggunakan observasi, wawancara dan dokumentasi. Pemanfaatan batuan Biaya Operasional Sekolah berdasarkan petunjuk teknis 2018 bisa dimanfaatkan delapan kriteria bagian yang digunakan dianggarkan berdasarkan Biaya Operasional Sekolah, adalah : peningkatan Standar Lulusan, peningkatan Standar Isi, peningkatan pengajaran dan kemampuan guru, peningkatan para siswa, peningkatan alat, dan peralatan, peningkatan dan penerapan tata kelola instansi, pengembangan melalui tata kelola, peningkatan perpustakaan.
\end{abstract}

Kata kunci: PembiayaanPendidikan, Efektifitas, Biaya Satuan Pendidikan, Bantuan Operasional sekolah

\section{PENDAHULUAN}

Pendidikan memiliki pengaruh terhadap perubahan sebuah negara, kemudian mampu meningkatkan kemampuan seluruh warga negara sebagai warga negara yang bertanggung jawab. Melalui siklus perubahan kemajuan dan akan menciptakan siswa semakin terpanggil untuk kemajuan pendidikan, baik secara perorangan meliputi masyarakat luas akan mengantarkannya menjadi insan-insan yang bersaing secara unggul. Sebagian sebab, negara merupakan pelindung orang banyak wajib meningkatan mutu pendidikan harga diri orang banyak semakin meningkat.

Perundangan negara Nomor 20Tahun2003 Tentang Sistem Pendidikan Nasional (SNP) menyebutkan bahwa setiap warga negara yang memiliki umur 6.5 sampai 15 tahun, wajib mendapatkan Pendidikan sekolah dasar dan Sekolah Menengah Petama. Dalam pasal 34 pada ayat 3 dalam UUD Republik Indonesia menyatakan bahwa pemerintah dan pemerintah daerah menjamin terlaksananya wajib belajar (atau d singkat menjadi WAJAR paling rendah sekolah dasar SD/SMP tidak boleh meminta anggaran, di ayat 3 juga menegaskan bahwa wajib belajar ini merupakan tangung jawab bangsa yang dilaksanakan oleh pihak sekolah sebagai tanggungan pemerintah baik daerah maupun pusat. Demi terkendalinya dan tercapainya/tertuannya amanah Undang-Undang itu maka pemerintah/pemerintah Daerah wajib melaksanakan pengayoman kualitas pendidikan bagi semua siswa pada tingkatan pembelajaran dasar yaitu di SD dan SMP dan pesantren setara.

Manfaat dari pendidikan secara gobal dan tertumpu pada peningkatan mutu pendidikan di seluruh bidang, maka pendidikan mampu menjadikan fokus utama bagi bangsa dan negara dan masyarakat sejak Indonesia merdeka. Berbagai cara dan upaya ditempuh, dilakukan untuk meningkatkan pelayanan pendidikan ke depan semakin berkualitas dari tahun ke tahun dan pendidikan dapat dinikmati oleh semua lapisan masyarakat. Upaya untuk meningkatkan kualitas pendidikan tersebut terus menerus 
dilakukan, mulai dari berbagai pelatihan, kecakapan untuk meningkatkan kualitas guru, perbaikan sarana dan prasarana pendidikan, peningkatan hingga kualitas tata kelola pendidikan di sekolah.

Berbicara tentang kualitas pendidikan jika berpedoman pada patokan yang telah di tentukan dalam peraturan pemerintah (PP) nomor 19 tahun 2005 tentang SNP. SNP merupakan sebuah standar kriteria Minimal tentang system Pendidikan (sisdiknad) di semunya daerah hukum negara kesatuan republic Indonesia berfungsi sebagai dasar.

Namun, tidak dapat dipungkiri bahwa kualitas pendidikan belum menunjukkan peningkatan yang signifikan. (World Bank) mendefenisikan bahwa mutu pendidikan di Negar Kestuan Repulik Indonesia di bawah ratarata, walau perluasan jaringan pendidikan bagi.Negara kita republic Indonesia telah mengubah sudut pandang bahwa untuk mengubah kualitas di berbagai elemen Pendidikan ini selam delapanbelas tahun(18) mulai dari 2002. Bapak Rodric Chaves selaku kepala perwakilan bank dunia menjelaskan kulaitas Pendidikan yang masih rendah dapat di lihat dari peringkat negara indonesi malah berada di tepat yang tinggi dari negara-negara disekitarnya/tentanggnya.indikator peringkat kualialitas Pendidikan di seluruh negeri nusantara/Indonesia

Berdasarkan hasil dari sisi jaringan pendidikan, total siswa sekarang dapat melanjutkan pendidikannya di sekolah meningatkan cukup signifikat. Demikian meningkatnya jaringan ini dilaksanakan dengan meningkatkan dana peningkatan keikutsertaan para pelaksana/pelaku dalam menegemenkan sekolah lebih baik, peningkatan akuntabilitas dan mutu tenaga pendidik dan kependidikan, sehingga memastikan siswa suces. Sangat di sayangkan hasil tersebut belum bias menaikan kualitas Pendidikan di wilayah NKRI. Salah satu Donatur bank dunia berpendapat masih banyaknya tantangan dan hambatan yang belum tersiapkan seperti tidak meratnya jaringan Pendidikan artinya masih banyaknya ketimpangan dalam Pendidikan di Indonesia. Dari sinin bank Dunia berpendapat harus ada perluasan yang merata dalam lagi sesuai dengan standar Pendidikan dunia baik secara praktik maupun teori selanjutnya pemerintah perlu meningkatkan kualitas guru melalui sertifikasi guru agar peningkatan kesejahteraan guru.

Rendahnya kualitas Pendidikan bukan hanya dipengaruhi oleh factor angaran misalnya kebijakan dalam system Pendidikan nasional, kurikulum dalam Pendidikan, sarana dan prasaran, biaya Pendidikan, guru dan tenaga kependidikan . ada beberapa factor yang menyebabkan kualitas suatu Pendidikan tidak mengalami peningkatan secara signifikat adalah (1) pendekatan education production fuction (out put) yang digunakan selama ini, dalam kebijakan penyelenggaraan Pendidikan nasional.. Lembaga sekolah di jadikan pusat produksi jika di penuhi seua masukan yang di butuhkan didalam kegiatan produksi maka akan menghasilkan output yang di kehendaki namun proses dalam Pendidikan itu sendiri kurang mendapatkan dukungan. (2) selama ini penyelenggara Pendidikan nasional selalu berpusat pada pemerintah pusat, sekolah hanya hanya menjadi sub ordinasi dari birokrasi diatasnya, sehingga kemandirian dalam pendidikan menjadi hilang, bukan hanya itu motivasi, kreatifitas dan keluwesan pun bias pudar dan yang ketiga (3) keikutsertaan steakcholder Lembaga Pendidikan dan masyaakt sekitar khusunya orang tua peserta didik dalam menyukseskan Pendidikan masih minim. . dan (3) keikutsertaan steakcholder sekolah dan masyarakat, khususnya wali murid dalam menyukseskan pendidikan selama ini masih sangat kecil.

Berkata dengan anggaran pembiayaan pendidikan, Kementrian Pendidikan dan Kebudayaan dalam peningkatan rencana pendidikan menengah universal memberikan khusus Bantuan Operasional Sekolah SD,SMP dan SMA sederajat di seluruh Indonesia (Kemendikbud, 2013). Petunjuk teknis Bantuan Biaya Operasional Sekolah bagian cara global di bidang pendidikan yang menggunakan anggaran terbesar dan langsung berhubungan dengan hajat kehidupan orang banyak dan masyarakat luas. Program Bantuan Biaya Operasional Sekolah bercita-cita untuk membantu meringankan beban warga masyarakat terhadap anggaran pendidikan dalam rangka Wajib Belajar Sembilan Tahun. Program biaya Bantuan Operasional Sekolah sangat berperan aktif untuk mempertahankan angka keikutsertaan bersekolah, yang dilihat melalui jumlah siswa semakin bertambah, selain itu pihak sekolah harus ambil bagian yang repenting dalam mengendalikan di samping itu juga harus ambil andil penting dalam peningkatan kualitas pendidikan dasar, serta tuntutan peningkatan akuntabilitas dan transparansi dalam pengelolaannya. Penggunaan biaya BOS di sekolah harus di dasarkan pada kesepakatan dan keputusan bersama antara tim manajemen BOS Sekolah( kepala sekolah, Bendahara dan Komite sekolah dan para guru), yang harus didaftar sebagai salah satu sumber penerimaan dalam RAPBS, di samping dana yang diperoleh dari Pemerintah daerah atau sumber lain yang sah.

Sekolah dasar negeri dan swasta yang di bawah naungan UPTD Pendidikan dan Kebudayaan V Kab. Aceh Tamiang yaitu SD 
Negeri Lung Manyo dan SD Swasta Lembah Jaya. Pada Tahun Anggaran 2018 SD Negeri Lung Manyo telah mendapatkan dana BOS sebesar Rp. 106.400.000, yang digunakan untuk berbagai macam pembiayaan pendidikan, diantaranya gaji tenaga bakti $(15 \%)$ dari dana BOS, pembayaran barang dan jasa, Pembayaran modal, belanja transportasi, belanja modal mesin, pembayaran modal kerussakan sekolah, pembayaran makan minum guru bakti dan pembayaran modal aset tetap. Penghitungan biaya pendidikan yang tepat sasaran, efisien dan efektif sangat dibutuhkan bagi sekolah dalam menetapkan biaya penyelenggaraan pendidikan. Sebelum sekolah tersebut menerima dana BOS, sarana dan prasarana di kedua sekolah tersebut masih kurang dan sangat membutuhkan alat dan sarana, dan temukan kelas yang kurang menegemen di dalamnya seperti atapnya bocor, kursi goyang-goyang meja yang patah perpustakaan tidak layak serta kamar mandi yang kurang memadai. Demikian setelah kedua sekolah tersebut menerima biaya BOS, perbaikan dari segi sarana dan peralatan mulai terlihat, karena dalam penggunaan anggaran bantuan sekolah (BOS) sudah di cantumkan untuk perawatan dan perbaikan sekolah seperti perbaikan atap, cat ruangan kelas perbaikan pintu dan jelndela sekolah bukan hnaya itu perbaikan WC juga dilakukan seperti sumur dan sanitasinya. Hal ini menjadikan suasana proses belajar mengajar menjadi aman dan terkendali

Dengan program anggaran Biaya Oprasional, SD Negeri dan SD swasta yang di bawah naungan UPTD Pendidikan dan Kebudayaan V Kab. Aceh Tamiang dapat membantu biaya khalayak terhadap anggaran pendidikan dalam rangka menuntaskan wajib belajar sembilan tahun yang berkualitas. Banyak, manfaat yang dapat dirasakan dengan adanya anggaran Bantuan Operasional Sekolah yaitu membebaskan biaya bagi seluruh siswa terhadap biaya operasional sekolah, membebaskan segala kutipan bagi seluruh siswa miskin dari seluruh pungutan dalam bentuk apapun, baik di sekolah negeri maupun swasta serta meringankan beban biaya operasional sekolah bagi siswa negeri maupun di sekolah swasta. Seterusnya, dengan berupa dana Biaya Operasional Sekolah khususnya di sekolah swasta, $50 \%$ dari keseluruhan bantuan Biaya Opeasional Sekolah bisa dipergunakan untuk pembayaran gaji tenaga Pendidik dan kependidikan guru, Operator, berstatus honorer. Hal ini menunjukkan bahwa ada manfaat yang begitu besar dengan hadirnya dana BOS bagi setiap sekolah.

Berdasarkan fokus masalah yang telah di kemukakan di atas, maka masalah penelitian merumuskan masalah. Rumusan masalah dalam penelitian ini adalah:
1. Bagaimanakah efektivitas pendayagunaan Bantuan Biaya Operasional Sekolah (BOS) dalam pembiayaan kualitas pendidikan terkait dengan 8 standar di SD Negeri Lung Manyo?

2. Bagaimanakah efektivitas pendayagunaan Bantuan Operasional Sekolah (BOS) dalam pembiayaan kualitas pendidikan terkait dengan 8 standardi SD Swasta Lembah Jaya?

\section{Tujuan Riset ( Penelitian )}

Berdasarkan rumusan masalah di atas, maka tujuan penelitian ini adalah:

1. Untuk mengenal efektivitas pendayagunaan Biaya Operasional Sekolah (BOS) dalam pembiayaan kualitas pendidikan terkait dengan 8 standar di SD Negeri Lung Manyo.

2. Untuk mengenal efektivitas pendayagunaan Biaya Bantuan Operasional Sekolah dalam pembiayaan kualitas pendidikan terkait dengan 8 standardi SD Swasta Lembah Jaya.

A. Manfaat Penelitian

Adapun manfaat yang diharapkan dari hasil penelitian ini yaitu:

1. Manfaat teoritis

a. Bagi instansi sekolah, riset ini dimaskudkan dapat memberikan konstribusi ide, pengetahuan, sebagai pola piker yang dapat dipertanggung jawaban.

b. Untuk memperluas jaringan komunikasi, riset ini mampu memberikan konstribusi tentang penggunaan biaya BOS yang telah ditelitidi dua sekolah.

\section{Manfaat praktis}

a. Bagi Pimpinan sekolah, riset ini diharapkan mampu dimanfaatkan sebagai buku rujukan dalam menentukan sikap di dalam pengambilan keputusan berhubungan dalam program sekolah, pengambilan keputusan mengenai penggunaan biaya Bantuan Operasional Sekolah, menjadi iktibar dan pertimbangan untuk melihat program sekolah yang kurang relevan dan transparan serta program sekolah yang harus diunggulkan terlebih dahulu.

b. Bagi Tim BOS, penelitian ini diharapkan dapat meringankan dalam manajemen alokasi penggunaan biaya BOS yang ideal, sehingga ke depannya lebih meningkat.

c. Bagi Masyarakat sekitar, riset ini diharapkan dapat memberikan pertanggung jawabkan serta secara terbuka mengenai mananjemen dana BOS yang ada di sekolah, sehingga masyarakat tetangga atau orang tua murid dan stekcholder dapat melihat dengan jelas pemanfaatan biaya dari pemerintah dengan bukti nyata program Kuitansi 7a dan K7 yang sudah dijalankan oleh sekolah. 
d. Bagi Peneliti, penelitian ini dapat dijadikan bahan rujukan pengetahuan dan pengalaman dalam menyusun karya tulis ilmiah terbaik

\section{KAJIAN TEORITIK}

1. Pengertian Penganggaran Pendidikan Menurut Daljono (2011:13), Anggaran pendidikan adalah proses dimana penghasilan dan pendapatan yang sudah ada dimanfaatkan untuk seluruh kegiatan dan membuat sekolah di seluruh wilayah geografis dan tingkat sekolah yang berbeda-beda. Sedangkan pendapat anggaran pendidikan ditinjau dari sudut pandang eknomi adalah Satuan uang menjadi alat ukur dalam merealisasikan anggaran, dalam mendapatkan barang atau jasa yang dicitacitakan akan menyumbangkan kemasukan/kegunaan pada zaman melinial atau waktu masa depan( Fattah (2012:6))

Lebih lanjut, anggaran pendidikan yaitu anggaran personil (privatecost) dan social cost atau di sebutjuga anggaran sosial. Sedangkan Angaran pribadi merupakan setiap anggaran pengeluaran keluarga untuk kebaikan sekolah atau disebut juga pengeluaran household expenditure. Sedangkan yang di maksut dengan anggaran social adalah setiap pengeluaran yang dikeluarkan oleh pendidik baik dari pihak sekolah maupun pajak yang di kumpulakn oleh pemerintah lalu digunakan untuk keperluan seklah dan dunia Pendidikan. Sedangkan biaya sendiri dikelompokkan mnejadi dua dimensi : Input dengan Output. Input dalam kata lain di sini seberapa besarnya anggaran yang di masukkan dari berbagai sumber anggaran, sedangkan yang di maksut Output disini seberapa besarny anggaran Pendidikan yang harus/wajib didanai Supriadi (2010: 4)

(Mulyono, 2010:72).Penganggaran pendidikan unggulnya adalah sebagian analisis terhadap sumber pendapatan dan penggunaan anggaran yang diperuntukan sebagai management pendidikan secara tepat dan efektif dalam rangka mencapai tujuan yang telah ditentukan.

\section{Pengertian Efektivitas}

Menurut Weihrich dan Koontz 2005:11 dalam Jejen Musfah hal : 7 Effectiveness is the achievement of objectives; efficiency is the achhievenent of the ends with the lead amount of rresources. . Efektifvitas sekolah mencapai visi sangat terkait banyak variable yaitu: pimpinan, sarana dan prasarana, guru, staf,biaya, pengelolaan,dan siswa. Sekolah sering tidak efektif karena ada satu, dua, atau lebih variable yang tidak berfungsi dengan baik. Mobil, tidak ada bensin ataubannya kempis, tidak berfungsi.

Sesuai defenisi atau tanggapan diatas dapat didefenisikan atau diartikan efektif yaitu keberhasilan misi sesuai atau memilah tujuan yang sesuai dari totalitas alternatif, memjadikan sebuah kebijakan yang sesuai dan sukses di dalam penerapannya. Sesungguhnya pengertian manajamen hampir sama tapi lebih singkat yaitu hasil yang dapat dituntaskan dengan ontime dan sesuai dengan rencana sebelumnya yang telah di tetapkan.

Arti lain Efektifitas, efektifitas adalah jangkauan hasil kesuksesan dengan pemilihan bagian teknik yang sudah ditentukan. Contohnya suatu pekerjaan bisa selesai dengan menggunakan alternatif cara yang sudah di tetapkan, maka cara tersebut sudah efektif. Setiap pekerjaan bila berhasil maka manajemennya sudah dapat dikatakan efektif dalam pertanggungjawaban terhadap unsur pekerjaan tersebut.

3. Pengertian Biaya Satuan Pendidikan

Dua hal yang paling penting kalua di lihat dari sudut pandang Sekolah Dasar yaitu adalah anggaran yang menyeluruh atau di sebut juga total cost dengan anggaran perpeserta didik atau di sebut juga dengan uniti cost. Anggaran ini berasal dari beberapa sumber seperti orang tua siswa, Negara, pemerintah daerah yang bertujuan melihat anggaran setiap tahun Fattah (2012:24).

Anggaran pendidikan bagi setiap siswa hanya dari Biayaan Opersionl Sekolah ( BOS ) yang benar-benar digunakan bagi kebutuhan sekolah, guru bakti, siswa dan kepada seluruh kegiatankegiatan sekolah dan perbaikan sarana prasarana juga untuk kegiatan meningkatan mutu pendidikan menuju sekolah standar pendidikan nasional.

4. Defenisi Bantuan Operasional Sekolah

(BOS)

Biaya Bantuan operasional sekolah (BOS) yaitu rencana negara yang pada dasarnya adalah untuk menyediakan sumber anggaran perorangan bagi satuan pendidikan dasar sebagai pelaksana program wajib belajar.

Menurut peraturan pemerintah No. 48 tahun 2008 tentang anggaran pendidikan, biaya non perindividu adalah anggaran sebagai bahan atau peralatan pendidikan habis pakai, dan biaya tak langsung berupa daya, air, jasa telekomunikasi, jasa listrik pemeliharaan alat dan peralatan, transportasi, konsumsi, pajak.

Menurut (Nurlina, 2013). Peran aktif pemerintah terhadap sekolah telah banyak usaha yang dilakukan dalam memajukan alam pendidikan seiring globalisasi, di antaranya yang berhubungan dengan pendidikan anak wajib belajar SD dan SMP selama Sembilan tahun, karena pemerintah memberikan subsidi biaya pendidikan terhadap pendidikan Sembilan tahun seperti subsidi SPP, dan Anggaran Bantuan Operasional Sekolah (BOS). Bantuan ini diberikan ke sekolah-sekolah bertujuan agar 
anak-anak Indonesia secara keseluruhan mengecap pendidikan minimal tamat SMP dan kepada orang tua anak agar tidak lagi dipungut biaya sekolah atau sekolah gratis.

1. Pengertian Pendidikan Berkualitas

Secara Global kualitas pendidikan yaitu serangkaian dan sikap secara keseluruhan dari jasa dan barang yang menunjukkan ability dalam memuaskan kebutuhan yang dicita-citakan atau yang tersirat. Pengertian kualitas pendidikan atau mutu pendidikan hendaknya tidak boleh diartikan sempit, tetapi harus ditelaah secara komprehensif yang meliputi semua komponen yang membentuk sistem pendidikan.

Menurut Alwi (2008: 768) mutu diartikan sebagai tingkatan baik buruknya sesuatu; kadar, derajat atau taraf; mutu. Dengan kata lain kelebihan yang dimiliki oleh seseorang atau tim. Sedangkan menurut Fattah (2012: 2) kualitas adalah sebuah upaya/jasa dalam mengoptimalkan fungsinya untuk memuaskan pelanggan. Terminology ini mula-mula di perkenalkan Plato dan Aristoteles dalam menyaatakan eksistensi suatu benda yang berkualitas dan untuk membedakan antara satu benda dengan benda lainnya. (Hamalik, 2014: 33).

Kementerian Pemdidikan dan kebudayaan dalam Nomor 67 tahun 2013 pada ayat 1 menyatakan kualitas Pendidikan mengarah pada delapan (8) standar Nasional dalam Pendidikan yatu : standar isi, standa kompetensi, standa $r$ proses, standar pendidik dan tenaga kependidikan, standar sarana dan prasarana, Standar pengelolaan, standa rpembiayaan dan standar penilaian Pendidikan.

Anwar (2013) menyatakan kualitas Pendidikan dapat di tinjau dalam 2 sisi yaitu : tinjauan normative dan. Dalam tinjauan normative kriteria instrinsik dan eksintrinsiklah yang menjadi pertimbangan utama. Anwar juga menambahkan bahwa ada perbedaan konsep tujuan konsep absolut dan relative. Dalam konsep absolut melihat sesuatu yang memiliki standar yang tinggi dan sempurna dialah yang berkualitas. Bila di lihat dalam dunia Pendidikan konsep absolut ini bersifat etitis, sebagian instansi saja yang bias mengacu mutu tinggi bagi peserta didik dan hanya sebagian peserat didik yang mampu memenuhi pembiayaannya, , sedangkan konsep relatif, mutu bukanlah tujuan akhir, melainkan alat ukur atas hasil akhir dari standar yang telah ditentukan. Kualitas yaitu serangkaian terstruktur yang membantu manusia menentukan apakah target yang diharapkan tercapai dengan memperbaiki setiap proses pendidikan.

Sebagai gambaran dari cakupan mutu yang terdiri input, proses dan output dapat dilihat sebagai berikut: a. Input

Menurut (Suryadi, 2012: 9-10). Sekolah merupakan sebuah instansi yang menerapkan pendidikan menghasilkan input manajemen, di mana seluruh karyawan harus bekerja sebagaimana fungsinya yang telah tertulis dalam aturan masing-masing.. Succes. Kesiapan input sangat diperlukan agar proses berjalan dengan baik.

(Baharudin, 2012:15) Mengarahkan peserta didik smemiliki makna peserta didik memiliki ilmu pengetahuan yang di dapatkan di sekolah di hayati dan mengamalkannya serta mamu belajar cara mengembagkan diri. Suatu Output bermuti tinggi apabila Lembaga pendidian menghasilkan prestasi kademik dan non akademik baik siswa mauput masyarakat sekolah di dalamnya.

Menurut Nurkholis(2003: 67).. siswa harus di berdayakan dalam mengusai ilmu pengetahuan dan teknologi (iptek)yang di ajarkan serta mampu mengamalkannya serta dan juga dapat mengembangkan diri dari ilmu pengetahuan dan iptek yang di peroleh. Akhirnya Output sekolah bias tinggi dengan menghasilkan prestasi akademik siswa dan demikian juga prestasi nonakademik dan lainnya.

b. Proses

Menurut (Suryadi, 2012: 11-12) Kegiatan peningkatan kualitas yang dilakukan lembaga sekolah membutuhkan sesuatu yang berkaitan dengan sekolah dan elemen lainya di dalamnya mendukung tujuan sekolah itu sendiri, supaya seleuruh rancangan yang di sudah di programkan berjalan dengan baik.

Menurut Rochaety, 2010: 118 Model peningkatan kualitas pendidikan menjanjikan kesadaran akan kualitas dalam institusi pendidikan tergantung kepada faktor iinterns, terutama sikap pengelolaan tingkat atas terhadap kualitas jasa pendidikan. Peningkatan kualitas bukan merupakan hasil penerapan cara spontan jangka waktu pendek untuk meningkatkan daya saing.

Menurut (Mulyasa, 2011: 168), pemimpin lembaga sekolah perlu memiliki contoh suri tauladan secara personalia yang meliputi,: motivasi, dorongan untuk menjadi pemimpin yang memiliki integritas kdan kepercayaan diri yang tinggi serta kejujuran serta inisiatif dan keartifitas serta orisinilitas yang memiliki kognifitas serta memiliki pengetahuan bisnis dan berkharisma. Itu semunay karena suatu pemimpin sekolah harus bisa memberikan inspirasi kepada semua masyarakat sekolah. Mulyasa (2011: 169) menjelaskan hasil kesepakatan dengan keampuan dan waktu pimpinan sekolah terlibat langsung dalam usaha usaha meningktakan mutu dan kualatis sekolah.

Proses pelaksanaan administasi dan fungsinya adminiastasi berjalan dengan baik hall 
ini dapat meingkatkan kualitas suatu sekolah. Ada beberapa hal yang harus di miliki oleh sekolah agar efektif : 1)rencana, 2)efektifnya proses belajar mengajar (PBM), 3)pemimpin instasi pendidikan yang kuat, 4) tertipnya lingkungan sekolah berserta aman, 5) administasi TENDIK yang efektif, 6) memiliki tim yang berintegritas tinggi, 7) kemandirian di sekolah, 8) ikutserta para petinggi sekolah (stakeholder), 9) menejemen yang yang terbuka, 10) kemampuan dan kemauan yang tinggi, melakukan perbaikan dan evaluasi yang keberlanjutan, 11) sekolah yang keberlangsungan hidup (sustainbilitas).

\section{c. Output yang di inginkan}

Hasil yang diinginkan sekolah adalah kinerja dari setiap sekolah.. Setiap elemen sekolah diharapakn memiliki peran dan menigkatkan kemampuan sekolah sehingga terbangun opini di masyarakat akan kemampuan prestasi BAIK NON AKADEMIK MAUPUN AKADEMIN di mata masyarakat seperti kemampuan dalam prestasi akademik dan non akademik. (Suryadi 2012: 12-13).

Baharuddin (2012:12-13) menambahkan yang di maksut

1) prestasi akademik di sini adalah hasil ulangan umum, ujian nasional (UN) lomba karya ilmiyah, banyaknya yang masuk dalam seleksi mahasiswa baru (SPMB), lomba olimpiade mata pelajaran., dan lainnya.

2) Sedangkan prestasi yang non akademik dimaksut disinin adalah prestasi siswa dalam ekstrakurikuler dan juga perilaku siswa yang sesuai dengan nilai dan norma masyarakat di sekitarnya.

3) Dan selai itu kinerja elemen sekolah lainnya seperti guru, kepemimpinan kepala sekolah, meningkta demikian juga dengan kepuasan dalam pelayanan, serta meningkatnya jumlah peserta didik yang masuk di sekolah tersebut .

\section{METODE PENELITIAN}

\section{Tempat dan Waktu Penelitian}

Tempat Penelitian tersebut dikerjakan/ dilaksanakan di SD Negeri Lung Manyo dan SD Swasta Lembah Jaya yang berada dibawah UPTD Pendidikan dan Kebudayaan V Kab. Aceh Tamiang. Adapun waktu pelaksanaan penelitian ini adalah dari bulan oktober 2018 sampai dengan Juli 2019

\section{Waktu Penelitian}

Riset ini dilakukan di UPTD Pendidikan dan Kebudayaan V Kab. Aceh Tamiang. Terdapat dua puluh tiga Sekolah Dasar di UPTD Pendidikan dan Kebudayaan V Kab. Aceh Tamiang, yang terdiri dari dua puluh satu Sekolah Dasar Negeri dan dua Sekolah Dasar
Swasta. Secara umum, UPTD Pendidikan dan Kebudayaan V Kab. Aceh Tamiang telah menyerahkan biaya Bantuan Operasional Sekolah (BOS) untuk tahun anggaran 2018-2019 kepada dua puluh tiga Sekolah Dasar yang terdapat di UPTD Pendidikan dan Kebudayaan V Kab. Aceh Tamiang. SD Negeri dan Swasta yang menjadi fokus tempat penelitian yaitu SD Negeri Lung Manyo dan SD Swasta Lembah Jaya.

\section{Metode dan Prosedur Penelitian}

Pendekatan kualitatif dan pendekatan kuantitatif menjadi pendekatan yang dilakukan dalama penlitian ini. Setiap data di peroleh melalui wawancara, dokumentadi dan pengamatan (observasi) di analisis dan di deskripsikan dalam beru[a narasi-narasi ilmiyah.

\section{Data dan Sumber Data}

Adapun yang dapat diperoleh sumber data dalam penelitian ini yaitu:

1. Data Primer/asli (data pokok), merupakan data yang diperoleh dari wawancara. Sumber data primer dalam penelitian ini meliputi;

a. Kepala SD Negeri Lung Manyo, kepala SD Lembah Jaya, Wakil Kepala sekolah, dan Bendahara.

b. Pegawai, pengumpulan datanya menggunakan teknik Purposive Sampling(data diambil secara sampel),. (Sugiyono, 2015: 300).

2. Data Sekunder ( pendukung), yaitu data yang diperoleh atau didapati untuk mendukung data primer. Data sekunder digunakan yaitu, studi kepustakaan UMSU dengan cara mempelajari dan mengutip dari berbagai konsep yang terdiri dari banyaknya literasi baik dari buku yang relevan, journal, majalah, koran, dan karya tulis lainnya dan dengan memanfaatkan dokumen tertulis, gambar, foto-foto, atau benda-benda lain yang berkaitan dengan aspek yang diteliti terutama dokumentasi-dokumentasi yang ada di SD Negeri Lung Manyo dan SD Lembah Jaya.

\section{Teknik dan Prosedur Pengumpulan Data}

Teknik dan prosedur pengumpulan data merupakan tahapan dalam penelitian yang sangat penting. Ada tiga (3) macam Teknik dan prosedur falam pengambilan data dalam penelitian ini yaitu : pengamatan (observasi) Ke SD Negeri Lung Manyo dan SDSwasta Lembah Jaya, wawancara, dan dokumentasi berupa Foto. F.Prosedur Data Analisis

Demi tercapainya tujuan dalam suatu penelitian maka dikakkan data analisis secara kualitatif dan kuantitatif. Data yang bersifat diskriptif di satukan atau dikumpulkan dan dihitung . biaya operasional menjadi hitungan dalam biaya satuan pemerintah, dengan hitungan 
yang menjadi biaya satuan Pendidikan dari pemerintah yaitu biaya operasional . dengan cara merinci sub-sub komponen biaya dan menjumlahkan secara menyeluruh. Satuan biaya atau setiapsub kumponen atau aktivitas dapat berbeda-beda setiap triwulan sebelum di anggarkan biaya satuan Pendidikan di SD Negeri Lung Manyo dan SD Swasta Lembah Jaya, bagian bendahara sudah membuat rencanan dalam menganggarkan biaya-biaya keluaran yang berhubungan dengan keperluan operasional sekolah di SD Negeri Lung Manyo dan SD Swasta Lembah Jaya.

\section{HASIL DAN PEMBAHASAN}

Sumber, BOS berkaiatan dengan pembiayaan Pendidikan dalam peraturan Undang-undang republic Indonesia nomor 20 tahun 2003 tentang system Pendidikan Nasional, setiap pendanaan Pendidikan menjadi tanggung jawab bermasa dari pemerintah daerah dan pihak masyarakat di sekitarnya. .Terkait dengan hal tersebut, sekolah dapat menerima bantuan berupa uang untuk keperluan, untuk penyelenggaraan pendidikan. Untuk membiayai proses pendidikan khususnya untuk belanja pendidikan sebagaimana yang disebut dalam Rencana Anggaran Pendapatan dan Belanja Sekolah (RAPBS), sumber dana diperoleh dari pemerintah dan orang tua Fatta(2012hal:25).

Meskipun tujuan utama program BOS adalah untuk pemerataan dan perluasan jaringan, program BOS juga merupakan program untuk peningkatan mutu, relevansi dan daya saing serta tata kelola, akuntabilitas dan pencitraan publik.

Sesuai program BOS, anggaran diterima oleh sekolah secara utuh, dan dikelola secara mandiri oleh sekolah dengan melibatkan Dewan Guru dan Komite Sekolah (Dirjen Mandikdasmen, 2009). Dengan demikian program BOS sangat mendukung implementasi penerapan MBS, yang secra umum bertujuan untuk memberdayakan sekolah melalui pemberian kewenangan (otonomi), pemberian flexibilitas yang lebih besar untuk mengelola sumber daya sekolah, dan mendorong dan partisipasi warga sekolah dan masyarakat untuk meningkatkan kualitas pendidikan sekolah.

Mengenai penggunaan bantuan dana operasional sekolah (BOS) di sekolah dasar (SD) Negeri Lung Manyo dan sekolah dasar (SD) Swasta Lembah Jaya menurut keterangan kepala sekolah dan hasil wawancara yang didukung dengan RKAS, pada dasarnya telah berjalan dengan efektif. Kepala sekolah telah melakukan pengelolaan dana BOS menggunakan juknis yang diterbitkan oleh pemerintah, dan semua kepala sekolah juga memahami isi buku tersebut.
Setiap pertengahan tahun atau pada saat tahu ajaran baru sekolah dasar negeri Lung Manyong dan sekolah swasta lembah jaya mendayagunakan dana BOS dalam pembiayaan mutu yang tertera dalam Rencana Anggaran Bos , setiap triwulan di buat permata anggaran dengan melihat peserta didik ditahun ajaran baru atau di bulan juli.

Adapun tatacara penganggarannya adalah misalnya angaran tahun 2019 harus di tinjau dulu atapunpun di sahkan tim menegemen di setiap kabupaten/kota di tempat sekolah asal yaitu satu tahun sebelumnya yaitu tahun 2018 di bulan juni ini untuk periode anggaran 2018 bulan juli, 2018 bulan juni. Untuk di bulan Desember tahun 2019 terjadi revisi anggaran perubahan yang harus sesuai dengan juknis bos yang terbaru ditahun 2019 hal ini bertujuan untuk lebih baik.pengesahan dari tim menegeman kota harus ada di setiap rancangan anggaran baru tersebut. Selain itu juga di bolehkan perubahan anggaran di setiap triwulan atau 3 bulan sekali.

Setiap dana bos yang cair di sesuai dengan juknis yaitu setiap awal bulan dan untuk implementasinya di akhir triwulan harus berjalan misalnya untuk anggaran triwulan pertama laopran cairnya di bulan januari laporan implemestasi/realisasi di bulan April, demikian juga di tahap dua atau triwulan kedua cairnya bulan April dan realisasinya bulan juli demikian juga di triwulan selanjutnya. Artinya 3 bulan awal cairnya dan realisasinya di tiga bulan akhir triwulan.

Berbagai kegiatan yang dilaksanakan oleh SD Negeri Lung Manyo dan SD Swasta Lembah Jaya telah melakukan rincian sesuai dengan juknis BOS. Bukan hanya melakukan rincian juga memilih dan memilah kegiatan yang terealisasi. Semua kegiatan yang terealisasi/terimplementasi di sesuaikan dengan kebermanfatan sekolah. Program yang terealisasi di SD Negeri Lung Manyo dan SD Swasta Lembah Jaya sesuai dengan persetujuan tim manajemen BOS kabupaten/kota. Sekolah akan melaksanakan kegiatan tersebut apabila semuanay program itu sudah di setujui tim secara efektif.

Adapun dalam jukni dana bos tahun 2018 bisa di gunakan menjadi 8 komponen yang di perbolehkan diantarany adalah, : 1 . pengembangan kompetensi lulusan(PKL), 2.pengembangan standar Isi(PSI), 3.pengembangan proses pembelajaran(PPP), 4.pengembangan peserta didik dan kependidikan(PSP), 5.pengembangan dan implemestasi mengemen sekolah, 6.pengembangan dan penggalian sumber dana, 7 . pengembangan perpustakaan, 8.pengembangan sarana dan prasarana. 
Kalau semua komponen diatas telah tercapai/terpenuhi pendanaan dari anggaran BOS masih terdapat sisa dana maka sisa dana BOS tersebut dapat digunakan untuk membeli alat peraga, media pembelajaran, mesin ketik, mobeler sekolah. Namun, dalam penelitian ini, peneliti mengkaji komponen pembiayaan dana BOS sesuai dengan yang tertera dalam RKAS SD Negeri Lung Manyo dan SD Swasta Lembah Jaya.

Kedelapan program dana bos yang dikalkulasi menjadi ditiga bulanberbeda dalam memanfatan dan pembiayaan untuk efektifitas segala program yang sudah di rancang. Segala macam program yang sudah dirancang dan ditentukan dan disesuaikan dengan peraturan pemerintah, instasi sekolah menjalankan sesuai juknis dan peratutan yang berlaku. Dilihat dari presntasi keefektifitas program kegiatan di SD Negeri Lung Manyo dan SD Swasta Lembah Jaya terlihat berjlaan sebagaimana rencangan dan terukur sesuai dengan rancangan yang sudah di onlinekan.

\section{KESIMPULAN}

\section{Simpulan}

Hasil penelitian yang telah dilakukan, maka dapat disimpulkan:

I. Pendayagunaan dana BOS di SD Negeri Lung Manyo efektif dalam pembiayaan kualitas pendidikan, hal ini menggunakan 8 standarisasi pembiayaan yang dilaksanakan oleh pihak sekolah adalah SKL yaitu pengembangan kompetensi kelulusan, pengembangan standar, Peningkatan Proses Belajar dan Mengajar (PBM), Peningkatan kompetensi siswa dan guru, perluasan alat dan peralatan (sarpras),pengembangan menegemen sekolah dan impleemtasinya serta pengembangan sumberdana Pendidikan dan mengoptimalkan perpustakaan serta menegemennya. Seluruh program pembiayaan tersebut terealisasi dengan baik dan tidak ada dana BOS yang tersisa.

2. Pendayagunaan Bantuan Operasional Sekolah (BOS) di SD Swasta Lembah Jaya efektif dalam pembiayaan mutu pendidikan, hal ini juga sesuai dengan program pembiayaan yang dilakukan oleh pihak sekolah yaitu peningkatan standar kompetensi lulusan ( tes), peningkatan standar isi, pengembangan proses belajar menggajar (PBM), dan pengembangan dalam penerimaan siswa baru dan tenaga guru, peningkatan alat pelaksanaan, bantuan dan penerimaan hasil biaya instansi dan pemanfaatan perpustakaan. Seluruh program pembiayaan tersebut terealisasi dengan baik dan tidak ada dana BOS yang tersisa.
3. Kendala dan hambatan pendayagunaan Bantuan Biaya Operasional Sekolah (BOS) dalam pembiayaan kualitas pendidikan di SD Negeri Lung Manyo dan SD Swasta Lembah Jaya, yaitu pencairan dana BOS pada tahap pertama selalu terlambat walaupun RKAS sudah diajukan.

\section{Rekomendasi}

Adapun rekomendasi yang di laksanakan oleh peneliti, adalah :

1. Dengan tercapainya efektivitas penggunaan biaya Bantuan Operasional Sekolah yang lebih efektif diharapkan sekolah mampu memenet pola pembiayaan operasional pemanfaatan biaya Bantuan Operasional Sekolah yang lebih sesuai dan efektif disertai dengan pengadaan sarana dan prasarana yang lebih mencukupi dan menambah jumlah pegawai/staff khususnya yang menangani biaya Bantuan Operasional Sekolah wajib di kedepankan dan bertanggung jawab.

2. Lembaga sekolah seperti kepala sekolah wajib mengadakan meeting tentang pemanfaatan pembiayaan Bantuan Operasional Sekolah bermanfaat meningkatkan keikutsertaan masyarakat focus kepada orang tua/wali murid shering pendapat antar orang tua dengan pihak instansi sekolah sehingga kualitas mekanisme yang transparan dalam pengelolaan biaya BOS tepat sasaran.

3. Seluruh survey penelitian mengkedepankan kajian lebih dalam dan lebih professional.

\section{DAFTAR PUSTAKA}

[1] .Anwar, Idhoci, 2013, Administrasi Pendidikan dan Manajemen Pembiayaan Pendidikan, Raja Grafindo Persada, Jakarta

[2] Alwi, Hasan, 2008, Kamus Besar Bahasa Indonesia, Balai Pustaka, Jakarta.

[[3] Baharuddin, 2011. "Pendidikan Gratis dan Kualitas Pembelajaran. Jurnal Administrasi Publik", Volume 8 (1) Juni 2011 ISSN 2088-527X (Print) ISSN 2548-7787 (Online).

[4]Daljono, 2011,Akuntansi Biaya Penentuan Harga Pokok \&Pengendalian, Badan Penerbit Universitas Diponegoro, Semarang.

[5] Hamalik, Oemar, 2014,Evaluasi Kurikulum, Remaja Rosdakarya, Bandung.

[6] MusfahJejen, 2015, ManajemenPendidikanTeori, KebijakandanPraktik, PT 
[7] Nanang, Fattah, 2012. Standar Pembiayaan Pendidikan, PT Remaja Rosdakarya, Bandung

[8] Nurkholis, 2003, Manajemen Berbasis Sekolah: Teori, Mode dan Aplikasi, Grasindo, Jakarta.

[9] Nurlina, 2013, "Women Vegetable Traders in Improving Children's Education in WestPadang",Juornal Manajemen dan Kewirausahaan, Vol. 4,No. 1 Januari2013.

[10] Sugiono, 2015, metode penlitian Pendidikan (pendekatan kuantitatif, kualitatif, RnD) Alfabeta, Bnadung.

[11] Supriadi, Dedi. 2010, satuan Biaya pendidikandasar dan mengenah, Remajarosda Bandung. 